\section{H.C. Andersen-donation til Det Kongelige Bibliotek}

15. Juni Fonden ${ }^{1}$ overrakte tirsdag den 10. maj 2011 det originale manuskript til H.C. Andersens eventyr De Vises Steen til Det Kongelige Bibliotek.

\section{af Erland Kolding Nielsen,}

Direktor, Det Kongelige Bibliotek.

\section{Introduktion}

Manuskriptet til eventyret De Vises Steen, der formodes at være det sidste større H.C. Andersen-manuskript i privat eje, og ukendt for nationalbiblioteket og lit- teraturforskningen, indtil det pludselig dukkede op på auktion i 1999. Det lå dengang uden for Nationalbibliotekets muligheder at erhverve det, og siden har det været omsat på det private marked flere gange til en pris, der gør det til ikke bare det dyreste H.C. Andersen-manuskript, men det dyreste danske håndskrift $\mathrm{i}$ det hele taget, der nogensinde er blevet handlet offentligt.

Efter den seneste auktion i november 2010, hvor manuskriptet endte med at blive trukket tilbage, købte 15. Juni Fonden manuskriptet direkte af den daværende ejer. Fonden overrakte d. 10. maj 2011 manuskriptet til Det Kongelige Bibliotek som Danmarks Nationalbibliotek med det sigte, at manuskriptet bevares og stilles til rådighed

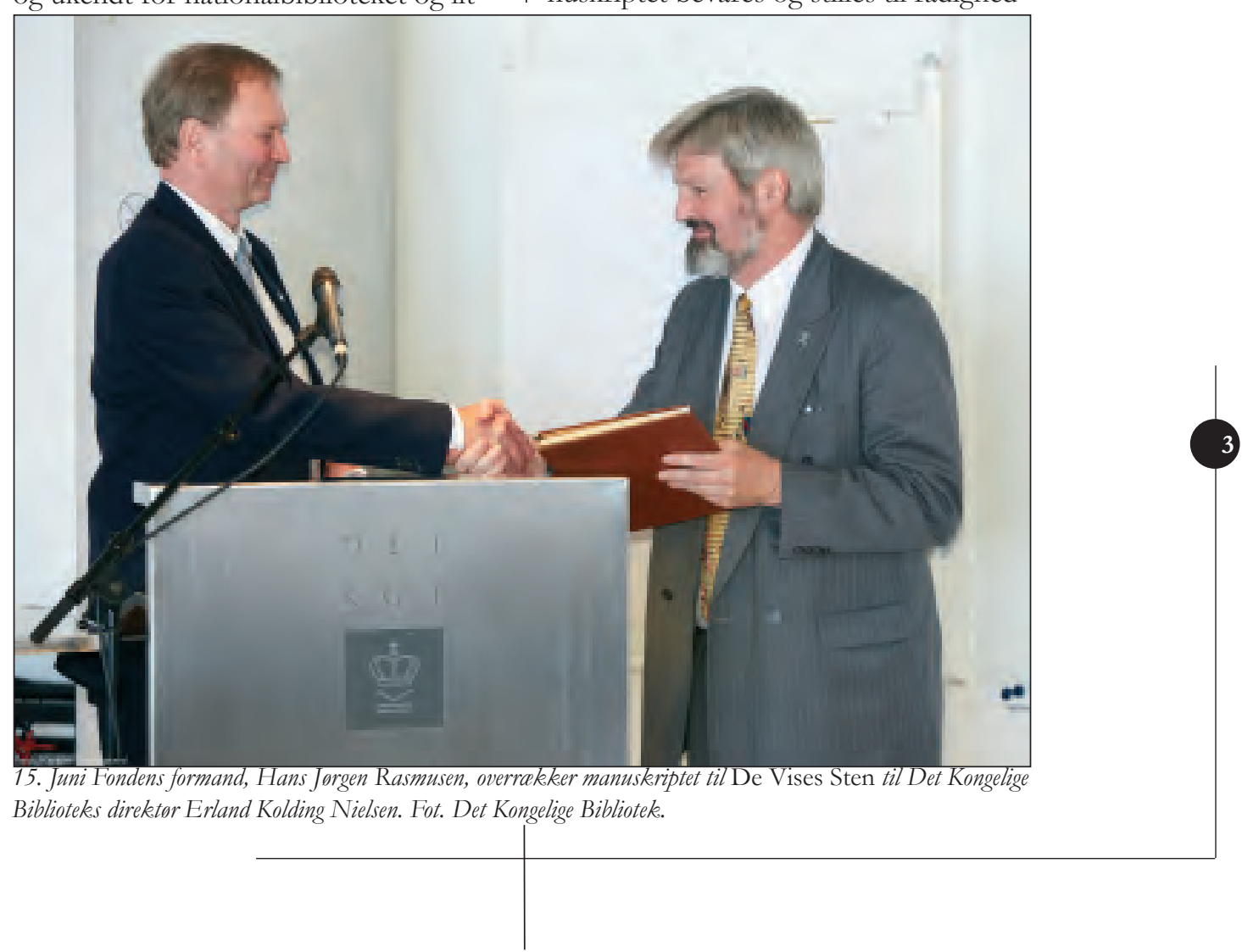


for offentligheden.

Eventyret, ${ }^{2}$ der behandler troen, der løser livets og dødens gåde, er skrevet i efteråret 1858, mens H.C. Andersen opholdt sig på Basnæs Herregård ved Skælskør. Det udkom første gang samme år i den meget udbredte Folkekalender for Danmark 1859. Manuskriptet forærede H.C. Andersen selv året efter under sin store Jyllandsrejse til præsten Jørgen Swane og dennes familie i Hjermind Præstegård. Manuskriptet har været ukendt, indtil det kom på auktion i 1999, og har således ikke kunnet udnyttes af forskningen før nu. Manuskriptet er allerede digitaliseret, ${ }^{3}$ og desuden planlægger Det Kongelige Bibliotek sammen med H.C. AndersenMuseet i Odense i nær fremtid en udstilling om nyfundne Anderseniana igennem de seneste årtier.

Overrækkelsen ${ }^{4}$ blev markeret med to festforelæsninger på Det Kon-

\section{Noter}

1 Om 15. Juni Fonden, se www.15junifonden. $\mathrm{dk}$.

2 Eventyret kan læses på Arkiv for Dansk Litteratur > www.adl.dk < og i ANDERSEN, Eventyr og Historier, bind 2, 2003, s. $357 \mathrm{ff}$.

3 Se: http://www.kb.dk/da/nb/materialer/haandskrifter/HA/e-mss/acc-2011_ gelige Bibliotek tirsdag den 10. maj 2011 ved henholdsvis forskningsbibliotekar Bruno Svindborg, Det Kongelige Biblioteks Håndskriftafdeling, og professor Klaus P. Mortensen, tidl. Københavns Universitet og Danmarks Pædagogiske Universitet, der er hovedredaktøren af ANDERSEN. H.C. Andersens Samlede Varker i 18 bind, den forste samlede udgave siden Samlede Skrifter (33 bind, 1854-1879; 2. udg. 15 bind, 1876-1880), som Det Danske Sprog- og Litteraturselskab udgav 2003-2007 på forlaget Gyldendal. Bruno Svindborgs forelæsning H.C. Andersen-overleveringen til og $i$ Det Kongelige Bibliotek bringes sammen med undertegnedes velkomst nedenfor som artikler, begge i revideret udgave. Klaus P. Mortensens At se eller ikeke se. Om H.C. Andersens 'De Vises Steen' blev trykt som essay i Weekendavisen d. 19. maj og bringes senere i revideret udgave $\mathrm{i}$ tidsskriftet Danske Studier i 2012.

18.html. Om digitale udgaver af H.C. Andersens manuskripter, se H.C. Andersen online under Nationalbibliotekets digitale webudgivelser på > http://www.kb.dk/da/ $\mathrm{nb} /$ tema/hca/index.html <

4 Billeder fra overrækkelsen og eventyret kan ses på > www.kb.dk <, klik Nyheder, presse, pressebilleder. 